\title{
For syncretism. The position of Buddhism in Nepal and Japan compared
}

'Héritiers de la logique grecque et $d u$ monothéisme juif, nous appliquons

$d$ 'instinct aux croyances religieuses le principe de contradiction; dieux et dévots se classent à nos yeux en groupes fermés, exclusifs jusqu'à l'antagonisme. Des statisticiens, sérieux à en mourir de rire, calculent le total des Bouddhistes, des Confucéens, des Sbintoistes. Un Hindou, un Chinois, un Japonais n'arriveraient pas à les comprendre' Sylvain Lévi, Le Népal, I, 173.

In this paper I wish to address the recently revived anthropological discussion of syncretism. By comparing Buddhism in two very different situations, I hope to show both how valid the anthropological critique of the concept of syncretism is and that it is still possible to apply the term in a non-ethnocentric way. ${ }^{1}$

In their important recent edited volume, Syncretism/Anti-Syncretism (1995), Stewart and Shaw sum up the state of play on the question. It is my impression that most anthropologists would now agree with them that there is no universally valid concept or definition of syncretism and that it is a waste of time to try and decide whether a given tradition is syncretic. On this perspective the only valid questions are 'When, where, how, and why do other people become concerned about, and fight over, the concept of syncretism?' Whether or not something is an example of syncretism is a

1 Fieldwork in Lalitpur, Nepal, from 1982 to 1984, was carried out thanks to a Leverhulme Study Abroad Studentship. Subsequent trips have been supported by the British Academy. I am also grateful to the Japan Foundation Endowment Committee which contributed towards the costs of fieldwork in Japan in 1991. First written up in this form in 1993, I have benefited from discussion of earlier versions of the argument with the members of seminars in Tokyo, Oxford and Lancaster, and with Andrew Beatty, J.-C. Galey, D. P. Martinez and Charles Stewart. I have been much influenced by Richard Gombrich's position on this question (Gombrich 1971; 1994). I should mention also Stefan Palmié's excellent piece of 1995: I have borrowed and reversed his title. 
sterile question for which there can never be an objective answer, since all traditions are syncretic. If the specialists of some traditions manage to propagate successfully a claim to authenticity and purity, the only appropriate analytic response is deconstruction and explanation.

Thus Shaw and Stewart (1995: 7) write:

Simply identifying a ritual or tradition as 'syncretic' tells us very little and gets us practically nowhere, since all religions have composite origins and are continually reconstructed through ongoing processes of synthesis and erasure. Thus rather than treating syncretism as a category an 'ism' - we wish to focus upon processes of religious synthesis and upon discourses of syncretism. This necessarily involves attending to the workings of power and agency. [original emphases]

While agreeing that it is important to pay attention to discourses of syncretism, I believe it is a mistake to assert that analysts must restrict themselves to the secondorder activity of discussing other people's judgments. This would be to erect a barrier between academic discourse on the one hand and ideological battles beyond the academy on the other, which, if it ever did exist, ought now to be recognised as an ideal rather than a fact.

Why have anthropologists been uncomfortable with the term 'syncretism'? In the first place, it seems too judgmental to be a legitimate or acceptable part of a social scientific vocabulary. Are not the observers quickest to slap the label 'syncretic' on phenomena precisely those who are least interested in capturing 'the native's point of view'? Furthermore, does not the use of the term 'syncretism' betray an unanthropological concern with the origins of particular practices (e.g. icons, symbols or rituals) at the expense of a contextualised understanding both of how they work now and of what they mean to the people who use them?

These concerns are entirely understandable. All too often external judgments have been imposed in exceedingly unhelpful ways. In the description of religious phenomena, this has often been done with great vigour and prejudice. Most anthropologists can cite Victorian condemnations of the religious practices of their area as superstitious, ritualistic, and 'mixed up', i.e. syncretistic. In more restrained language similar descriptions are still being written.

Nonetheless, I shall argue that the term 'syncretism' can still be saved for general social scientific discourse. However, for reasons to be considered, there will almost certainly never be agreement about just which practices, religions, symbols and myths are syncretic. The basic definition of syncretism which is tacitly accepted by those who use the concept in academic writings is, I believe, as follows: 'the unsystematic (or unsystematised) combination within a single tradition of elements which their originators intended to be kept apart'. ${ }^{2}$ Such a definition avoids the extremely pejorative force of some committed usage but does not pass the buck of judgment altogether. As I have indicated, I do not think we should throw up our hands with the post-modernists and say that all traditions are equally syncretic, equally unstable and equally hybrid.

In his earlier work on supernatural survivals in the modern Greek worldview,

2 For a useful survey of attempts to define syncretism within religious studies, see Droogers (1989). 
Stewart advanced a valuable distinction between a syncretic situation, for example the Pagan-Christian encounter in the early centuries of the first millennium, and a synthetic tradition, for example Greek Orthodoxy in later centuries, when paganism no longer survived as a separate tradition, though elements of it had been absorbed into the now relatively stable Greek Orthodox tradition. ${ }^{3}$ From this position Stewart now recants, thinking that he wrongly adopted the viewpoint of his own Greek informants. He asks, 'Once the idea of stable traditions is introduced, how far away can the notion of pure traditions be?' (Stewart 1995: 28). This, I think, is the counsel of despair. I do not believe one is committed to fundamentalism by the simple recognition that some traditions are more stable or more systematic than others, and it is a serious anthropological question to ask why.

All religious traditions take elements from different sources. In different ways most are involved in debates about origins and authenticity. It is surely wrong to argue that anthropologists can never make judgments about the validity of these arguments. Peel (1968) was right to say that the Nigerian Aladura churches he had studied were not actually syncretic, as the missionary churches charged, since all the elements of their practice were authentically Christian - though not a kind of Christianity the missionaries themselves approved of.

My proposed definition of syncretism is an attempt to capture more or less what lies behind contemporary academic usage. However, even if everyone agreed to this definition (I am under no illusion that they will), they could with perfect justice disagree about which phenomena should be labelled syncretic because of different understandings of the definition's component terms. Even if we take the concepts of 'tradition' and 'system' as unproblematic - and clearly different religions have very different ideas about their relationship to their past and about what constitutes being systematic - different adherents of the same religion frequently have very different attitudes to the 'originators'. Some, the fundamentalists, see the original founder's intentions as paramount; others, the traditionalists, see no way of knowing these outside of the institutions that have passed down the practices and teachings of the religion. For the latter, the succession of priests or cardinals count as originators; for the former, they are no better than distorters of the original message. And these two are by no means the only possible positions. For example, many religions have no single founder; in the case of many 'elements' of religious practice no one knows who the 'originator' was, or, if they do, what his, her, or its intentions were.

Furthermore, even if two parties agreed on what counts as syncretism, they might still evaluate it differently. One side might regard it as a solecism to disregard the founder's intentions; another might believe that the founder's spirit is honoured better in a syncretic format not possible or plausible in the founder's time. There can also be disagreement between adherents of the same tradition over how far a world religion should go in adopting local cultural forms and symbols: one person's inculturation or 'skill in means' is another's syncretic aberration. As Stewart (1995) shows, regional traditions of scholarship have evaluated syncretism very differently: in Africa, thanks to the hostile view missionary churches have taken of African churches, it has been basically a pejorative term; in America, by contrast, it was for long a positive term ascribing some sort of agency to cultural adaptations by those of low status.

3 Stewart (1991: 7). This distinction is an external analytical one; no doubt the protagonists in the early Pagan-Christian encounter had diverse, and more complex, assessments of the relationship. 
Syncretism is an essentially contested concept." The term 'essentially contested concept' was first introduced by Bryce Gallie (1964: ch. 8), and has since been taken up by several anthropologists, notably by L. Rosen (1984: 185-7). The point is that even if we agree on what syncretism is, it is likely that there will be valid arguments on both sides whenever the question of whether to apply it in a particular case arises. As with concepts like 'democracy' and 'art', contestation is part of the term's very use. Anthropologists need to exercise caution therefore, but need not excise the term from their vocabulary, as Aidan Southall (1975: 274), for instance, declares that he has done with the term 'tribe', to mention a term once thought relatively innocuous.

\section{What kind of religlon is Buddhism?}

Buddhism, wherever in Asia it has been practised, in virtually all of its very different forms, has been frequently and vehemently condemned by western observers as syncretic. The basic problem here is that the observers expected Buddhism to be a religion like Christianity: exclusive towards all other religions, and providing for all the possible social and supernatural needs of its adherents (Gellner 1990). It is only now that some Buddhist modernists aspire to remake Buddhism because they have adopted western notions of what a religion is: Gombrich and Obeyesekere (1988) have labelled this development 'Protestant Buddhism'.

The exclusivity of Christianity as conventionally understood hides from view the fact that religious practices can serve very different social purposes or, put another way, that religion as social practice has many different aspects. These aspects or purposes may be listed as follows (there may be some I have missed, but the argument does not depend on the list being exhaustive or definitive):

1 The legitimation and expression of the household or family group

2 The legitimation and expression of the locality (or village or tribal section or caste, etc.)

3 The legitimation and expression of the nation or ethnic group

4 The sanctification of the stages of the life cycle

5 The socialisation of the young and the provision of a moral code

6 The provision of psychological and practical help in case of misfortune, especially illness

7 The provision of a path to salvation from all ills, i.e. a soteriology

Christianity aspired to satisfy all these needs or aspects, and frequently did so. Many religions focus on only one or two of these. Shintoism may be said to lack a

4 Droogers (1989: 20) also argues that 'the definition of syncretism ought to include the element of contesting ... Syncretism is in the first place contested religious interpenetration' (italics in the original). Gallie $(1964: 161,168)$ lists a number of formal criteria for a concept to be essentially contested, which it seems to me that 'syncretism' satisfies. The only problematic one is that it should be appraisive, where 'syncretism' is predominantly pejorative, i.e. negatively appraised. The 'live examples' that Gallie gives are Christianity, democracy, art and social justice. 
soteriology, Hinduism to provide dozens of them. A moral code is frequently lacking from non-scriptural religions. ${ }^{5}$

As far as Theravada Buddhism is concerned, the basic argument was made eloquently by Gombrich in 1971 . Early Buddhists set out to provide a soteriology, that is to provide a path to salvation and only secondarily, if at all, to help with worldly problems. Early Buddhism, to which the Theravada form remained broadly faithful, also incorporated a moral code, since it was a core part of its teachings that the practice of morality was the indispensable first step on the Buddhist path. But the other five religious aspects it did not aspire to fulfil. This means that Theravada Buddhism is always accretive (Gombrich 1971: 49). It always coexists with some other system or systems which satisfy, for Theravada Buddhists, these other needs. In order to find cohabitation acceptable, Buddhist specialists require that these other systems acknowledge Buddhism as the supreme overarching system and as the path to salvation, and that their practices should not conflict too blatantly with Buddhism's own teachings. In some contexts this means that Buddhist clerics have accepted animal sacrifices, where these are performed in what are defined as non-Buddhist contexts. At other times and places, Buddhists have campaigned successfully for the suppression of such sacrifice.

Mahayana Buddhism, which first emerged some time around the turn of the common era, several hundred years after the death of the Buddha, maintained much the same position. However, the development of Tantric Buddhism, several hundred years later again, with its elaborate ritual and its stress on secret teachings defining an initiated elite, encouraged and legitimated the growth of a Buddhist priesthood. As such, Buddhism could aspire to fill all the roles listed above, and could provide rituals and practices for all or most of them. This happened in Nepal, as I have described in detail (Gellner 1992), and in Tibet (Samuel 1993) where Buddhism became the overwhelmingly dominant political and cultural force. However, in China and Japan different literate religious traditions already existed, responded and reacted to the arrival of Buddhism with new forms and developments, and so Buddhism remained, as it was in its older form, essentially accretive. In this respect, Japanese Buddhism is more similar to Theravada Buddhism, the type of Buddhism geographically, historically, liturgically and scripturally most distant from it, than it is to the Mahayana and Tantric Buddhism of Nepal and Tibet with which it is normally classified.

Let us turn explicitly to the question of syncretism. Just because a given religious system does not provide for all seven aspects, and therefore coexists with some other tradition(s) and system(s) which provide for the others, this is not sufficient reason to think that we are dealing with syncretism. Even if we take the entire religious field as a single tradition - against the actors' own definitions - there may be a systematic relationship between the different sub-systems within the field, with one tradition providing the overall framework. Tambiah's Buddhism and the spirit cults in northeast Thailand (1970) is a classic account of the Thai religious field as made up of four different systems, defined in the local context by the differences and oppositions between them: Buddhism; the sukbwan rites of Brahmanism; the cult of guardian spirits; and the cult of malevolent spirits (Tambiah 1970: 338). Good structuralist that

5 See Southwold (1978) for a list of twelve criteria, no one of which is found in all religions. Since there is no single ever-present characteristic, Southwold concludes that religion is a polythetic category. 
he is, Tambiah is not concerned to identify syncretism, but simply to show how the different systems are defined in opposition to each other.

\section{Nepal}

By 'Buddhism in Nepal' I refer to the Buddhism of the Newar people of the Kathmandu valley, and exclude the Tibetan Buddhism practised by the Tamangs, the Sherpas and others of Tibetan culture; this usage can be justified on the grounds that historically, and still for many Nepalese today, the term 'Nepal' refers primarily to the Kathmandu valley and not to the modern state of Nepal. This Nepalese Buddhism exists in a strongly Hindu context. It is in fact the last surviving remnant of Indian Buddhism and has for that reason been of great fascination to Indologists and Sanskritists, from Sylvain Lévi to Bernhard Kölver and Siegfried Lienhard (Lévi 1905; Kölver and Sakya 1985; Lienhard 1984).

The practitioners and followers of Nepalese Buddhism have had continuous contact with Tibetan Buddhism (Lewis 1989), both because Newars have long traded and practised goldsmithing and image-casting in Tibet, and because Tibetans come on pilgrimage to the holy sites of the Kathmandu valley and have contributed to their renovation. Some Newars have become monks and others lay followers in the Tibetan tradition, and in the late nineteenth or twentieth century most significant Newar Buddhist sites have been adorned with Tibetan-style prayer wheels. These facts notwithstanding, Nepalese Buddhism is not, and never has been, an offshoot of Tibetan Buddhism. Its natural orientation is to India, and since Indian Buddhism no longer exists, its frame of reference is in fact Hindu. ${ }^{6}$

Whether or not the term 'syncretism' has been used, the cardinal question observers of Nepalese Buddhism have therefore asked themselves, is this: How much of what Newar Buddhists do is really Buddhist? How much is due to the Indian culture of their Buddhism? And how much is a later borrowing from Hinduism, due to the destruction of Buddhism in India, and its encapsulation in Nepal in a thoroughly Hindu environment? ${ }^{7}$

If one adopts a modernist, historical view of Buddhism, as the teaching of Sakyamuni Buddha, then all of Mahayana Buddhism is in effect syncretic, since it incorporates forms of worship and scriptures not envisaged by him. In the same way, Tantric Buddhism, with its still later scriptures, modelled on Shaiva prototypes (Sanderson 1995), and its divinities clearly borrowed likewise from Shaivism, is still more syncretic. Theravada monks do in fact regard Tantric Buddhism as no better than Hinduism, and they seem always to have done so (Gellner 1992: 323).

However, once one accepts Mahayana and Tantric Buddhism as independent traditions with their own originators, then the complex rituals and baroque pantheon of Newar Buddhism - similar though they may be to Hindu (Shaiva or Vaishnava) prototypes - are not, in terms of my original definition, syncretic. An example may make this clear. There is a particular form of Avalokiteshvara, the principal bodbi-

6 On the problems with the category 'Hindu', see Sontheimer and Kulke (1989). For present purposes, Hinduism may be taken as synonymous with Shaivism.

7 I have argued elsewhere (Gellner 1990) that the overriding focus on this question is a sign of immaturity in the study of Buddhism. 
sattva of Mahayana Buddhism, known as Srsti-kartr-lokeshvara or 'Lokeshvara in the process of creation'. The term for creation, srsti, implies emission from one's own substance, and the icons of this form show Lokeshvara emitting all the Hindu gods from his body. The term, and the icon, are clearly borrowed from the similar Hindu form of Vishnu in the act of creation. But is this syncretism? It is in accord with the Mahayana Buddhist practice of adopting Hindu (or elsewhere, other local cultural) forms and using them to express the ultimate superiority of the Buddhist path. The same logic is also characteristic of relations between the various sectarian traditions within Hinduism: Shaivism and Vaishnavism both in different ways try to absorb and include the other as an inferior version of themselves. The copying of the icon of Vishnu in order to express Buddhist ideas is therefore in accord with the intentions of the originators of Mahayana Buddhism (cf. Pye 1978), as far as these can be divined, and it is far from unsystematic.

In cases such as this, one has a mature synthesis of elements of heterogeneous origin. As Stewart remarks in a passage already discussed, all world religions incorporate elements of diverse origin, and this alone should not be enough to label them syncretic. The exotika, the supernatural figures inherited from the Greeks' pagan past and still recognised by the Greeks today, 'form a complementary, although antithetical, part of a whole [namely, Greek Orthodoxy, as popularly practised], not a separate "anti-structure", (Stewart 1991: 7).

Two further examples may show where the term syncretism can legitimately be applied. Of the three cities of the Kathmandu valley, Lalitpur is traditionally the most Buddhist. In the royal palace at the city's centre there is a famous gold window that shows this same figure, Srsti-kartr-lokeshvara. It is said that the as yet unpublished inscription on the window shows that it was given to Siddhi Narasingh, the king of Lalitpur in the seventeenth century, by a Buddhist goldsmith, as was a golden throne. However the window is framed by images which clearly suggest that the figure is not in fact Lokeshvara but Vishnu: Vishnu's mount, Garuda, lies immediately below it. The combined figure thus manages to be all things to members of both religions in the city. The Buddhist subject made a donation that was acceptable both to his fellow Buddhists, the majority in the city, and to his Hindu monarch. It was a deliberate piece of syncretism in a particular political situation.

The same interpretation should undoubtedly be made of another striking iconographic form. These are the numerous chaityas (Buddhist cult objects) dating from the second half of the nineteenth century, all but one in the city of Kathmandu, which combine a regular chaitya form with a water-course that is clearly borrowed from a shivalinga, the main iconic symbol of Shaivism. This was the Rana period, the most intensely Hindu that the Newar Buddhists have had to live through. It seems very likely that the Buddhists of Kathmandu, the capital, felt this official pressure more than others. This syncretic iconographic form which became so popular among them was, in effect, a way of saying, 'We Buddhists are really no different from Hindus'.

So far I have argued that the Newar Buddhist tradition taken as a whole is synthetic but not syncretic, although certain relatively unimportant parts of it are syncretic. It must be admitted, however, that one important and fundamental feature of Newar Buddhism could well be seen as a syncretic adoption from Hinduism: the fact that its sacerdotal class is made up from two sub-sections of a hereditary caste (Gellner 1992: 164-6, 267-8, 307; Gellner and Quigley 1995: ch. 7). The two sections are the higher Vajracharyas, who are the 'Buddhist Brahmans' and the slightly lower 
Shakyas. The Shakyas, together with the Vajracharyas, constitute the married parttime monks who run the monastic temple complexes that house the important cults of Newar Buddhism. What evidence we have suggests that the originators of both Mahayana and Tantric Buddhism intended their ways of deliverance and/or rituals of initiation to be open to all those of sufficient application and ability, regardless of background. Against this, however, it must be said that the now embattled traditionalist Newar Buddhists hold that the 'originators' of their tradition are precisely their ancestors who did intend the positions of Vajracharya and Shakya to be hereditary.

Moving now to consider Newar Buddhists, as opposed to Newar Buddhism, it is necessary to distinguish an inner core, which is largely priestly, from the bulk of the laity. The inner core is formed by the sacerdotal caste, the Vajracharyas and Shakyas, plus the foremost lay Buddhist caste in Kathmandu, known as Uray or Tuladhar. The major practices of the core groups are in general, and with the one important caveat noted, not syncretic by the canons of their own tradition. Ancestor Worship (shraddha) modelled on the Hindu rite is performed, but it is done in a strictly Buddhist idiom. Hindu gods may be worshipped, but they are subordinated to Buddhist bodhisattvas and Buddhas. Just as the Theravadin Buddhist may legitimately worship non-Buddhist spirits and Hindu gods, as long as it is not for soteriological purposes (Gombrich 1971), so too may the Newar Buddhist.

Matters become more complicated as soon as one considers other Newars. These may be divided into three groups: those who have Vajracharyas as their domestic priest, those who have Brahmans as their domestic priest, and those low castes who have neither. In the traditional classification, Newar households who have Vajracharyas as domestic priests are called buddbamargi, 'those who follow the path of the Buddha'. This includes, of course, all Vajracharyas, all Shakyas and all Tuladhars. Those families who have Brahmans as their domestic priests are known as shivamargi, 'those who follow the path of Shiva [i.e. Shaivites]'.

For present purposes, it is interesting to consider those Newars other than Vajracharyas, Shakyas and Tuladhars, who have Vajracharya priests, i.e. the bulk of the Buddhist 'laity'. Among them it is common to find genuinely syncretic attitudes and practices. That is to say, some of them really believe that Buddhist and Hindu paths are equally possible and valuable paths to salvation (an idea other Newars are also liable to express in mixed company); and in their own practice, they often combine the rituals of both religions.

The majority of this group of Buddhist laity is formed by the peasant or Maharjan caste. For them Buddhism provides a framework of life-cycle rituals (Aspect 4 above), especially ancestor worship, and ritual assistance in worldly problems (Aspect 6). For those few who seek it, it also provides a soteriological idiom (Aspect 7). Although Newar Buddhism does provide moral teachings (Aspect 5), these reach only the inner core of the religion's adherents and a few rare individuals from other castes. This is one of the main criticisms made by the Theravada modernists who have so successfully proselytised among Newar Buddhism's traditional followers: that it is a system of ritual rather than of morality or doctrine. Aspect 2 (expressing solidarity at the level of the neighbourhood or locality) is, again, performed by Buddhism only for Vajracharyas, Shakyas and Tuladhars. Aspect 3, national solidarity, is not really aspired to by local Buddhism, though it could be said that the divinity/bodhisattva Karunamaya is the national god of the city and one-time kingdom of Lalitpur. It is the Hindu cults promoted by the King which preeminently satisfy this aspect. Maharjan neighbour- 
hood organisations usually focus on Hindu gods such as Bhairava or one of the mother goddesses. ${ }^{8}$

To different extents, therefore, and differently according to the caste and individual, Newar Buddhism provides for all seven of the religious aspects listed above. Its specialists have adapted it further in providing more life-cycle rituals than any other form of Buddhism: there is a form of wedding ceremony, the central ritual of which (a lustration of the joined heads of the couple) is derived from Tantric initiation. A systematic relationship to Hinduism has emerged which (a) permits the followers of Newar Buddhism to worship Hindu gods, while yet remaining within a Buddhist framework, and, conversely therefore, also provides a bridge whereby any worshipper of a Hindu god can become a Buddhist devotee; and (b) provides alternative rituals, festivals, and divinities so that Buddhists do not need to worship in a Hindu idiom if they do not so wish. The first strategy I have called that of multivalent symbols; worshipping the high Hindu gods Vishnu and Shiva as bodhisattvas is an example of this. ${ }^{9}$ The second strategy, following Lienhard (1978), I call parallelism.

One consequence of this complex situation is that individuals and castes have considerable choice in the precise manner in which they articulate and act out their relationship to Buddhism and Hinduism. Just how they present themselves can be seen as the outcome of various pressures, not least among them the attitude of the state. Newar Buddhist clerics, the Vajracharyas and Shakyas, have had to adapt to the Hindu preferences of the local monarchs for a long time, and the development of parallel practices and multivalent symbols is part of their survival strategy. The prominence of Tantric forms of their religion also has much to do with this, since it is apparent to Newars that in the field of Tantric religion Buddhism and Hinduism share much.

Where other (lay) castes are concerned, there is much greater freedom to become Hindus, by degrees. A Nepali proverb says 'Jasko sakti usko bbakti' ('Whose power, his devotion'): in other words, 'People tend to adopt the religious style of whoever holds power'. This is particularly apposite for those high-caste Shresthas and middleranking Maharjans who have become Shresthas over the last 150 years. In the Mallaperiod kingdoms of the Kathmandu valley before 1769, the majority of the Newar population had Buddhist priests. The new Gorkhali rulers, and especially the hereditary Rana prime ministers of the period 1846-1951, were strong Hindus, as already noted. Shresthas were increasingly employed as civil servants and it was only natural for them to adopt the religious customs of their masters. Upwardly mobile peasants, who were able to turn themselves into Shresthas, especially in the outlying settlements in the north and east of the valley, imitated them by giving up their Vajracharya priests, employing Brahmans and adopting a Hindu religious style very little different from that of the dominant, Nepali-speaking Parbatiya population. ${ }^{10}$ For most of these, as for the high-caste Newars who had always been Hindu, it is not usually a question of adopting a syncretic attitude. In fact, it may be rather a question of abandoning a syncretic combination of Hinduism and Buddhism for a predominantly Hindu viewpoint, in which Buddhism is seen as a mere branch or sub-sect of Hinduism.

8 There are occasional exceptions, such as the Maharjans of Gahchen, Lalitpur, for whom the local Buddhist stupa is the main shrine.

9 For an interesting discussion of multivalency in Java, see Beatty (1996).

10 This process has been documented for the town of Sankhu by Rosser (1966). 
In the large cities of Kathmandu and Lalitpur it may properly be said that the Maharjan or peasant caste has just such a syncretic attitude. They all have Vajracharya priests but when pressed on the question, as in the national census, the majority today describe their religion as 'Hindu'. They accept both religions as equally valid and practise the rituals of both, though they know full well that the priests whom they use are themselves more purist. They are intensely proud of their own traditions, a pride that has probably increased with their improved economic position since 1951 . Their syncretic outlook reflects the reality of their position in a double-headed caste system with two great traditions: they are the tenants and clients of high castes of both persuasions, and it is in their interest to remain equally attached to both.

To sum up: within traditional Newar Buddhism syncretic attitudes on the part of the laity were not actively combatted, but were rather recognised as a lower stage or level of a distinctively Buddhist path. Toleration of syncretism was therefore both a defence against Hinduism and a bridgehead for counterattack. Today, with the introduction of modernist standards of 'purity' and 'authenticity', Newar Buddhism is condemned by the western-educated, self-appointed spokesmen of Buddhist reform for this very strategy, as well as for the similarity of much of its internal organisation to those forms of religious relationship identified as typically Hindu.

\section{Japan}

Buddhism in Japan presents a very different spectacle to Buddhism in the Kathmandu valley of Nepal. It is not just that the population of Japan is 120 million, that of the Kathmandu valley approximately 1 million; nor that Japan is now a rich and successful industrial society, with vibrant Buddhist institutions clearly at home in the modern world. The history of Buddhism there is also very different. There have been many different sects based on different Buddhist scriptures. Some were Tantric, practising rituals very similar to those of Nepal and Tibet (the Shingon, and to some extent Tendai, sects). Others were anti-ritualist and anti-elitist (the Pure Land sects). There were therefore many different ways of being a Buddhist practitioner and different ways in which these practitioners related to their main local rival, Shintoism. Such variety was not characteristic of the small world of traditional Newar Buddhism.

In Japan, unlike Nepal, Buddhism did not attempt to become an all-encompassing religion. It remained, in Gombrich's term, accretive. There was no strategy of parallelism, whereby, whenever a rite was offered by the competing religion, it too evolved its own version for its adherents. Buddhism in the Kathmandu valley faced a system that provided many rituals and a complete system for life, namely Hinduism. Buddhism in Japan began as the dominant religion of the elite, and it was the native cults which were forced to adapt, find a name - Shintoism - and textual charters for themselves, and begin to compete with Buddhism. Until the Meiji restoration of 1868, Buddhist specialists in Japan could easily tolerate and exist in complementary harmony with Shintoism, since for the most part they were, and saw themselves as, the dominant partner.

Buddhist monks and priests controlled the sphere of death and the afterlife. They therefore provided soteriology (Aspect 7) and, through worship of the ancestors, Buddhist ritual symbolised the continuity of the household (Aspect 1). The other Durkheimian aspects (Aspects 2, 3 and 4, death rituals excepted) were happily ceded to Shinto cults. The socialisation of the young (Aspect 5) came to be conceived of as the 
task of Confucianism, itself brought from China by Buddhist monks. Dealing with misfortune (Aspect 6) was the sphere of a variety of specialists and divinities, some Buddhist, some Shinto, some Taoist, and some a mixture.

The complementarity of Buddhism and Shintoism was not total, however. It was not only that certain Shinto intellectuals rejected its subordination. My own research in a Tokyo neighbourhood focused on the existence of two different types of Buddhist temple, the danka temple and the shinja temple (Gellner 1996). The former are the classic and by far the more common type, specialising in death and open only to those 'donors' (danka) who are attached to them. The latter are open to anyone, to any 'believer' (shinja). They include some of the larger and more spectacular temples of Japan. They specialise in worldly matters. In the most paradigmatic case, the temple attempted as far as possible to avoid any contact with death or the worship associated with it. This type of temple, its head priest told me, is 'just like a Shinto shrine'. In other words, the possibility of Buddhism providing for all religious aspects was always present. Buddhism existed in pre-Meiji Japan in a complementary synthesis with Shintoism, but in the final analysis it did not actually need Shintoism.

As long as Buddhism was recognised as the senior partner and as the sole guide to salvation, there was nothing in this situation that could be seen as syncretic from a Mahayana Buddhist perspective. The confidence of Buddhist priests in this situation can be seen in the fact that any divinity not strictly Buddhist was defined as Shinto. This is symbolised by the placing of a Shinto holy gate (torii) before the altar or shrine. Many Indian or Hindu gods brought to Japan with Buddhism, such as Benten (Sarasvati), were included in this 'Shinto' category, and these gods are, even today, controlled by Buddhist priests.

In the Tokugawa era there were at various places, such as at Ise shrine, Shinto specialists who resisted Buddhist ideological hegemony and sought to establish a purely Shinto religious perspective, but they were in a minority and do not seem to have been significant in their own time. More characteristic of the pre-Meiji period seems to have been the kind of shrine described by Grapard (1984), where the practices of the two religions were inextricably melded. Overnight, with the changes introduced by the Meiji reformers, the priests had to decide to become either Shinto or Buddhist; in this case, as in many others, they became Shinto, removed all Buddhist icons, and excluded anything that might be construed as Buddhist. In the pre-Meiji period it was common to find important shrines of, for example, the war god Hachiman, in the precincts of a Buddhist temple and run by Buddhist monks. Now seen as a purely Shinto divinity, he was at that time identified with the Buddhist bodbisattva Maitreya. With the 'reforms' of the early Meiji period, the two institutions were forcibly separated and began to be run by entirely separate functionaries. In the pre-Meiji period what I have dubbed in the Nepalese context multivalent symbolism was evidently very common in Japan: Shinto kami (gods) were routinely identified with Buddhist bodhisattvas (Herbert 1967: 46; Kamstra 1989: 141; Miyake 1996: 124); with the Meiji separation, the Japanese had to learn to see Buddhism and Shintoism as two separate religions and not as two complementary religious orientations, aspects of a single way of life.

The new way of viewing religion was inspired by European examples. Where the Tokugawa regime had insisted that all settled Japanese be attached to a local Buddhist temple, and had used the temple's priest as a census taker, the Meiji reformers decided that Shintoism was the truly Japanese religion. They persecuted Buddhism, decided to 
purify Shintoism, and to use it as the basis of a modern sense of nationhood (Ketelaar 1990). Thus began the process of building what is known as State Shinto, with its worship of the emperor and its view of the nation as a single household under his direction (Hardacre 1989). In short, the old way of practising Buddhism and Shintoism had come to seem syncretic under the impact of Christian-derived views of religion and the power of the West.

And yet even today the ordinary practice of most lay Japanese continues the old complementarity. Most still use Shintoism for rites of birth, youth and marriage (with considerable syncretism in the latter), and Buddhism for death (Reader 1991: chs. 3-4). Among those who stick to traditional forms, and who seek a soteriological practice, most do so as Buddhists. There are, of course, many new religions. Some of these encourage their followers to maintain their traditional attachments; some more wellknown ones, such as Soka Gakkai, are hostile to any other religious attachments; many are frankly syncretic, incorporating Shinto, Buddhist and Christian elements (Koepping 1994).

Outside the new religions, it is only in the personal rituals of the clergy of the two religions and of the Imperial Palace that there is a determined attempt to break the old complementarity. Buddhist priests now get married in a Buddhist ritual (in the preMeiji era it was only in the Pure Land sects that there were married Buddhist priests). Shinto priests have developed Shinto death rituals and Shinto graveyards. The Emperor is now buried in an invented Shinto rite and the new one is consecrated to rule in another. Both of these would have been Buddhist rituals in the pre-Meiji period (Ketelaar 1990: 44, 92; Smith 1995: 31).

In terms of the earlier analysis, there was an emerging synthesis in Tokugawa Japan in which Buddhism was the dominant and accretive partner. This was reversed with the Meiji restoration so that joint practice of Buddhism and Shintoism has come to seem syncretic. It is important to note that both the earlier synthesis and the later separation were the outcome of government action. ${ }^{11}$

\section{Conclusion}

This rapid survey of two contrasting situations of Buddhism's coexistence with other religions suggests that we need to distinguish four types of situation.

1 Bricolage. The combination of numerous elements of diverse origins with no stable synthesis envisaged. Post-modern perspectives lead to the collapsing of all phenomena into this one kind.

2 Syncretism. Here disparate elements are combined, usually of just two traditions; the actors may recognise it and see it as a positive thing, as with the Maharjan peasants or modern ecumenical movements, or may be defensive about it and attempt to deny it.

3 Synthetic traditions, such as any of the so-called world religions, which are made up of elements of different origin, but combine them in a systematic way, with an internal logic that relates and explains them.

These three should probably be approached as ideal types: in particular situations it is

11 Kamstra (1989) argues that as far as ordinary Japanese are concerned, Buddhism, Shintoism, etc. are different aspects of a single religious tradition. Syncretism is therefore simply not an issue for them. 
possible that transitions from one form to another may occur. ${ }^{12}$ All three need to be distinguished from the fourth situation, though they may also be found within it:

4 Complementary and accretive coexistence of more than one traditions. This is the situation which I have illustrated with examples from Thailand and Japan. In such cases, several traditions coexist, often in a structured hierarchy, but also often in open or tacit competition. The mutual influence of such traditions is highly likely to give rise to some syncretic forms, but the analysis of such situations is extremely complex and all simplistic labelling is to be avoided.

In applying the term syncretism, I have thus tried to argue that though one may have good reasons for using it, there are also good reasons for supposing that it will always be controversial. As academic observers we need always to ask whether it is a question of an entire tradition or of a single ritual, or some other aspect of practice. We have to acknowledge that interested participants are very likely to take the part for the whole and make sweeping judgments more detached observers cannot concur with. Questions of power are certainly central to this whole debate. Stewart concludes his latest piece by saying that 'Social anthropologists and sociologists should try to identify where these contests [over syncretism] are taking place and render accounts of them, rather than allow themselves to be trapped into contributing to them' (Stewart 1995: 37).

Unlike Stewart, I do not think that academics who make judgments of this sort have necessarily been 'trapped' into contributing to a power struggle. To refuse to do so in the name of ethical and political purity seems to involve abandoning crucial distinctions about the social organisation of power, and precisely to weaken the attempt to 'render accounts' which Stewart claims should be the purpose of examining syncretism in the first place.

\author{
David N. Gellner \\ Department of Human Sciences \\ Brunel University \\ Uxbridge \\ Middlesex \\ $U B 83 P H$ \\ $U K$
}

\title{
References
}

Beatty, A. 1996. 'Adam and Eve and Vishnu. Syncretism in the Javanese Slametan', Journal of the Royal Antbropological Institute, 2: 271-88.

Droogers, A. 1989. 'Syncretism. The problem of definition, the definition of the problem', in J. Gort, H. Vroom, R. Kernhout and A. Wessels (eds.), Dialogue and syncretism. An interdisciplinary approach. Grand Rapids: William B. Erdmans; Amsterdam: Editions Rodopi.

Gallie, W. B. 1964. Philosophy and the bistorical understanding. London: Chatto and Windus.

Gellner, D. N. 1990. 'Introduction. What is the anthropology of Buddhism about?', Joumal of the Anthropological Society of Oxford, 21: 95-112.

1992. Monk, bouseholder and tantric priest. Newar Buddbism and its hierarchy of ritual. Cambridge: Cambridge University Press.

12 I was pleased to discover that Michael Pye (1994), arguing from within religious studies, has come to a similar conclusion: if carefully done, syncretism can be distinguished from synthesis. 
1996. Temples for life and temples for death. Observations on some Shingon temples in Tokyo, Journal of the Anthropological Society of Oxford, 27(3).

Gellner, D. N. and Quigley, D. (eds.) 1995. Contested hierarchies. A collaborative ethnography of caste among the Newars of the Kathmandu valley, Nepal. Oxford: Clarendon Press.

Gombrich, R. F. 1971. Precept and practice. Traditional Buddhism in the rural highlands of Ceylon. Oxford: Oxford University Press. Reissued 1991 as Buddhist Precept and Practice. Delhi: Motilal Banarsidass.

1994. 'A Buddhologist's impression of Japanese Buddhism', in P. Clarke and J. Somers (eds.) Japanese new religions in the west. Folkestone: Japan Library/Curzon Press.

Gombrich, R. F. and Obeyesekere, G. 1988. Buddhism transformed. Religious change in Sri Lanka. Princeton: Princeton University Press.

Grapard, A. G. 1984. 'Japan's ignored cultural revolution. The separation of Shinto and Buddhist divinities in Meiji (shimbutsu bunri) and a case study: Tônomine', History of Religions, 23: 240-65.

Hardacre, H. 1986. Kurozumikyô and the new religions of Japan. Princeton: Princeton University Press.

1989. Shinto and the state, 1868-1988. Princeton: Princeton University Press.

Herbert, J. 1967. Shintô. At the fountainhead of Japan. London: George Allen and Unwin.

Kamstra, J. H. 1989. 'The religion of Japan. Syncretism or religious phenomenalism', in J. Gort et al. (eds.), Dialogue and syncretism. An interdisciplinary approach. Grand Rapids: William B. Erdmans.

Ketelaar, J. E. 1990. Of heretics and martyrs in Meiji Japan. Buddhism and its persecution. Princeton: Princeton University Press.

Koepping, K.-P. 1995. 'Manipulated identities. Syncretism and uniqueness of tradition in modern Japanese discourse', in C. Stewart and R. Shaw (eds.), Syncretism/Anti-Syncretism. The politics of religious synthesis. London: Routledge.

Kölver, B. and Sakya, H. 1985. Documents from the Rudravarna-Mahavihara. Sankt Augustin: VGH Wissenschaftsverlag.

Lévi, S. 1905. Le Nepal. Etude Historique d'un Royaume Hindou. Paris: Leroux.

Lewis, T. T. 1989. 'Newars and Tibetans in the Kathmandu valley. Ethnic boundaries and religious history', Journal of Asian and African Studies, 38: 31-57.

Lienhard, S. 1978. 'Problèmes du syncrétisme religieux au Népal', Bulletin de l'Ecole Française de L'Extrême Orient, 65: 239-70.

1984. 'Nepal. The survival of Indian Buddhism in a Himalayan kingdom', in H. Bechert and R. F. Gombrich (eds.), The world of Buddhism. London: Thames and Hudson.

Martinez, D. P. 1990. 'The Dead. Shinto aspects of Buddhist ritual', Joumal of the Anthropological Society of Oxford, 21: 199-209.

Miyake, H. 1996. 'Rethinking Japanese folk religion. A study of Kumane Shingen', in P. F. Kornicki and I. J. McMullen (eds.), Religion in Japan. Arrows to heaven and earth. Cambridge: Cambridge University Press.

Palmié, S. 1995. 'Against syncretism. "Africanizing" and "Cubanizing" discourses in North American orisà worship', in R. Fardon (ed.), Counterworks. Managing the diversity of knowledge. London and New York: Routledge.

Peel, J. D. Y. 1968. 'Syncretism and religious change', Comparative Studies in Society and History, 10: 121-41.

Pye, M. 1978. Skilful means. A concept in Mabayana Buddhism. London: Duckworth.

1994. 'Syncretism versus synthesis', Method and Theory in the Study of Religions, 6(3): 217-29.

Reader, I. 1991. Religion in contemporary Japan. Basingstoke: Macmillan.

Rosen, L. 1984. Bargaining for reality. The construction of social relations in a Muslim community. Chicago: Chicago University Press.

Rosser, C. 1966. 'Social mobility in the Newar caste system', in C. von Fürer-Haimendorf (ed.), Caste and kin in Nepal, India and Ceylon. Bombay: Asia Publishing House.

Samuel, G. 1993. Civilized Shamans. Buddhism in Tibetan societies. Washington DC and London: Smithsonian Institution Press. 
Sanderson, A. 1995. 'Vajrayana. Origin and function', in Buddhism into the year 2000. International conference proceedings. Bangkok and Los Angeles: Dhammakaya Foundation.

Shaw, R. and Stewart, C. 1995. 'Introduction. Problematizing syncretism', in Stewart and Shaw (eds.), Syncretism/Anti-Syncretism. The politics of religious synthesis. London: Routledge.

Smith, R. J. 1995. 'Wedding and funeral ritual. Analysing a moving target', in J. van Bremen and D. P. Martinez (eds.), Ceremony and ritual in Japan. Religious practices in an industrialized society. London: Routledge.

Sontheimer, G. D. and H. Kulke (eds.) 1989. Hinduism reconsidered. Delhi: Manohar.

Southall, A. 1975. 'Forms of ethnic linkage between town and country', in B. Dutoit and H. Safa (eds.) Migration and urbanization. Models and adaptive strategies. The Hague: Mouton.

Southwold, M. 1978. 'Buddhism and the definition of religion', Man (n.s.), 13: 362-79.

Stewart, C. 1991. Demons and the Devil. Moral imagination in modern Greek culture. Princeton: Princeton University Press.

1995. 'Relocating syncretism in social science discourse', in G. Aijmer (ed.), Syncretism and the commerce of symbols. Göteborg: IASSA.

Stewart, C. and R. Shaw (eds.) 1995 Syncretism/Anti-syncretism. The politics of religious synthesis. London, Routledge.

Tambiah, S. J. 1970. Buddhism and the spirit cults in north-east Thailand. Cambridge: Cambridge University Press. 